\title{
LE PRINCIPE DE PRÉCAUTION EDITIONS ODILE JACOB / LA DOCUMENTATION FRANÇAISE, PARIS
}

Philippe Kourilsky

Geneviève Viney

Publicado em 2000, o livro transcreve o relatório apresentado ao Primeiro Ministro da França, em 29 de novembro de 1999. O trabalho foi solicitado aos autores, tendo em vista "as preocupações da população: transparência da informação, respeito à precaução em matéria de saúde pública e de meio ambiente, sem que se ignorem, contudo, os benefícios trazidos pela ciência". O Chefe do Governo francês esperava que fossem propostos "os princípios de reflexão e de ação, a partir de dispositivos jurídicos, suscetíveis de melhorar o preparo e o seguimento das decisões que os poderes públicos devem tomar, assim como o acesso à informação pelos cidadãos". Esperava, também, que essas propostas pudessem "contribuir para definir a posição da França no cenário internacional, visando especialmente à revisão da diretiva comunitária sobre os organismos geneticamente modificados e no quadro das discussões sobre a aplicação do princípio de precaução no seio da Organização Mundial do Comércio". Os mandatários dessa missão foram: Philippe Kourilsky, diretor de uma unidade de pesquisa no Instituto Pasteur e membro do conselho científico do grupo Rhône-Poulenc e consultor da sociedade Pasteur-Mérieux-Connaught, no momento da redação do relatório, e Geneviève Viney, professora de direito civil e diretora do Centro de Pesquisa em Direito Privado na Universidade de Paris-l.

Algumas das personalidades consultadas para a elaboração do relatório, professores universitários e/ou pesquisadores do Centre Nacionale de Recherche Scientifique - CNRS, prestaram suas informações em forma de artigos, com muitas referências bibliográficas, que foram anexados ao livro. Assim, Mathilde Boutonnet e Anne Guégan apresentam o histórico do princípio de precaução; Christine Noiville e Pierre-Henri Gouyon, o princípio de precaução e os organismos geneticamente modificados: o caso do milho transgênico; Marie-Angèle Hermitte e Dominique Dormont, as proposições para o princípio de precaução à luz do "caso da vaca louca"; e Michel Setbon, o caso do sangue contaminado confrontado ao princípio de precaução. A partir da introdução, na qual os autores discutem o conteúdo conceitual do 
princípio de precaução, o relatório - ocupando 230 páginas - foi concebido em três partes, que tratam, respectivamente, do estado atual do princípio de precaução, dos aspectos normativos e judiciários do princípio de precaução, e da conclusão e recomendaçōes.

Para compreender a situação atual do princípio de precaução, é dada grande importância às suas implicaçōes sociais. Discute-se, especialmente, a necessidade crescente, sentida por grande parte das pessoas, de verem os temas envolvidos nas situações de crise ser tratados de modo transparente. Isso requer, daqueles que devem decidir, o esforço de traduzir as informações técnicas indispensáveis ao entendimento popular do fenômeno em causa, e, do público em geral, maior interesse pela maneira como se desenvolve a ciência. Os autores não ignoram, contudo, o aspecto econômico, componente essencial de uma ampla analise custo/benefício, que subjaz a todo julgamento em que se invoca o princípio de precaução. Assim, considerando os objetivos imediatos do trabalho que thes foi encomendado, eles apresentam os dez mandamentos da precaução:

"I - Todo o risco deve ser definido, avaliado e graduado.

Il - A análise dos riscos deve comparar os diferentes cenários de ação e de inação.

III - Toda a análise de risco deve comportar uma análise econômica que deve resultar em um estudo custo/benefício (em sentido amplo) preliminar à tomada de decisão.

IV - As estruturas de avaliação dos riscos devem ser independentes, mas coordenadas.

$V$ - As decisões devem, tanto quanto possivel, ser revisáveis e as soluções adotadas, reversíveis e proporcionais.

VI - Sair da incerteza impõe uma obrigação de pesquisa.

VII - Os circuitos de decisão e os dispositivos de segurança devem ser não apenas apropriados, mas coerentes e eficazes.

VIII - Os circuitos de decisão e os dispositivos de segurança devem ser confiáveis.

IX - As avaliações, as decisões e seu segmento, assim como os dispositivos que para elas contribuem, devem ser transparentes, o que impõe a etiquetagem e a traçabilidade.

$X$ - O público deve ser informado ao máximo e seu grau de participação ajustado pelo poder público."

Em seguida, os autores tratam de aspectos práticos ligados à implementação do princípio de precaução, dedicando especial atenção à perícia e à avaliação dos riscos. Sua proposta para a França envolve o reconheci- 
mento da perícia pelas instituições cientificas (o que deve implicar, inclusive, a destinação de meios) apoiada nas academias e a criação da agência de perícia científica e técnica (Agence d'Expertise Scientifique et Technique), criando-se uma carreira de perito e um sistema de publicações. Essa estrutura seria responsável pela gerência de dois grupos de peritos: o primeiro composto exclusivamente de peritos executando análises científicas e técnicas, o segundo com alguns peritos representando o primeiro grupo e "economistas, atores sociais e representantes do público". E, alargando seu espectro de abrangência, discutem as novas exigências normativas postas pela evolução científica e a correspondente necessidade de adequar as estruturas de implementação e controle ao requerido pela norma; apresentam os dispositivos específicos relativos à saúde, à alimentação e ao meio ambiente, focos de incidência prioritária do princípio de precaução, e algumas idéias para melhorar a transparência e orientar a relação com o público. Para encerrar a primeira parte Philippe Kourilsky e Geneviève Viney discutem o caso dos organismos geneticamente modificados.

A segunda parte, contudo, reveste-se de maior interesse, pois trata dos aspectos normativos e judiciários do princípio de precaução, até o momento ainda pouco examinados. Busca-se, por exemplo, verificar se, independentemente dos textos normativos que fazem referência ao princípio de precaução, ele possui o valor normativo que permite sua aplicação direta sem o suporte de qualquer outro texto. E a conclusão dos autores, após ampla pesquisa centrada na experiência européia e norte-americana, é que "nem os textos, nem a reflexão doutrinária, nem a prática judiciária permitem dar uma resposta definitiva à questão". Entretanto, orientados sobretudo pelo documento As linhas diretrizes para a aplicação do princípio de precaução elaborado pela Comissão das Comunidades Européias (Direção XXIV), eles dão a seguinte definição: "O princípio de precaução define a atitude que deve observar toda pessoa que toma uma decisão concernente a uma atividade que se possa razoavelmente supor que comporte um perigo grave para a saúde ou a segurança das gerações atuais ou futuras, ou para o meio ambiente. Ele se impõe especialmente aos poderes públicos, que devem fazer prevalecer os imperativos de saúde e de segurança sobre a liberdade de comércio entre os particulares e entre os Estados. Ele exige que se adotem todas as disposições que permitam, por um custo econômico e socialmente suportável, detectar e avaliar o risco, reduzi-lo a um nível aceitável e, se possivel, eliminá-lo, informar as pessoas interessadas e recolher suas sugestões sobre as medidas imaginadas para tratá-lo. Esse dispositivo de precaução deve ser proporcional à amplitude do risco e pode ser a todo momento revisto".

Orientados por tais balizas, Philippe Kourilsky e Geneviève Viney encerram essa parte examinando as conseqüências judiciárias do princípio de precaução, particularmente na discussão da validade do ato administrativo e a possível influência que ele deve exercer sobre a responsabilidade. É sobretudo instigante o tratamento dado à responsabilidade jurídica, uma vez que Geneviève Viney é especialista no tema e grande entusiasta da respon- 
sabilidade objetiva. Assim, após verificar, com fartura de argumentos, as tendências favoráveis a uma acentuação da responsabilidade penal daqueles que decidem, ela passa a examinar a possibilidade de o princípio de precaução provocar um recuo dos casos de responsabilidade sem culpa, especialmente daqueles fundados na "teoria do risco". Aqui parecem faltar argumentos para "desmentir categoricamente a hipótese de um retorno à responsabilidade por culpa sob a influência do princípio de precaução". De fato, o que se pode deduzir da simples observação social revela que os filósofos e teóricos do direito têm-se esquecido de que a responsabilidade se situa entre a retribuição e a imputação, ou seja, ela envolve tanto a indenização quanto a procura da verdade. E que, portanto, a responsabilidade por risco, deixando de analisar o comportamento que gerou o dano, desconhecendo, assim, o homem (negligente ou imprudente), ou não verificando sua falta de conhecimento ou sua competência técnica insuficiente (imperícia), não satisfaz o prejudicado, que não mais aceita apenas ser indenizado, mas deseja a identificação do culpado. Essa falta de argumentos convincentes não invalida, contudo, a excelente pesquisa desenvolvida, envolvendo mesmo o terreno, ainda muito pouco cultivado, da responsabilidade daqueles que influenciam quem decide.

Convencidos de que "a formulação atual do princípio de precaução não é uma inovação fundamental, mas que ela acentua a obrigação de quem decide de considerar os riscos que não são totalmente verificáveis", os autores concluem sistematizando várias recomendações, algumas já sugeridas no trabalho. Elas envolvem, entre outras, a construção de uma estrutura nacional dedicada à perícia; a adequação da pesquisa e do ensino às prioridades postas pela saúde pública, à segurança alimentar e à saúde dos ecosistemas; a necessidade de transparência do sistema de tomada de decisões; uma atenção especial para as media; e, quanto à responsabilidade, uma série de alterações legislativas e o alargamento da interferência do Poder Judiciário, reconhecendo "aos juízes o poder de exigir, em casos de simples ameaça de dano grave para a saúde, a segurança ou o meio ambiente, as medidas de conservação ou de volta ao status quo ante que se imponham para prevenir esse risco". Em suma, LE PRINCIPE DE PRÉCAUTION de Philippe Kourilsky e Geneviève Viney é, sem dúvida, uma obra de consulta recomendada para quem toma decisões em saúde pública e meio ambiente e para todos que sentem sua segurança ameaçada por tais decisões, bem como por aqueles que têm o dever funcional de assegurar o respeito aos direitos e ao interesse público. 